\title{
ZROBIE TO BEZ ZWLOK... \\ THE CATEGORY OF NUMBER IN THE TEACHING OF POLISH AS A FOREIGN LANGUAGE TO UKRAINIAN-SPEAKING PEOPLE
}

(THIS ARTICLE WAS TRANSLATED FROM POLISH BY JAKUB WOSIK)

Keywords: category of number, singularia tantum nouns, pluralia tantum nouns, teaching Polish as a foreign language, Polish language, Ukrainian language

\begin{abstract}
This article discusses the peculiarities of the category of number of Polish and Ukrainian nouns. To indicate the problem areas related to the teaching of the category of number to Ukrainian-speaking persons, the author analysed Polish and Ukrainian lexemes in terms of their fulfilments of the grammatical category of number. The article presents the contexts which may trigger errors, which in turn may cause a comical effect or distort communication. The data were collected from Polish and Ukrainian dictionaries, as well as the National Corpus of Polish and the Ukrainian Text Corpus.
\end{abstract}

The category of noun number, in particular singularia tantum and pluralia tantum nouns peculiar for the group, often become the focus of Slavic linguists. The provenance and development of the grammatical category of number and its instances in Slavic languages were analysed by Vladimir Degtyarev (1987; 1989). The word formation, semantic and inflective characteristics of pluralia tantum nouns, and the history of their development in Polish were discussed in works by: Anna Andrzejczuk (2007, 2009), Anna Cieślikowa (1992), Andrzej Dyszak (1999, 2001), Teresa Friedelówna (1968), Joanna Gradkowska (1989), Ewa Rogowska (1991), Jolanta Tambor (2017), and Sebastian Żurowski (2014); and in Ukrainian: Lesia Altytseva (2003), Oksana Korin (2010), Alla Ternova (2004), and others. Analyses of the semantics of number forms, in particular

*iryna.bundza@1nu.edu.ua, Ivan Franko National University of Lviv, Faculty of Philology, Chair of Polish Philology, 1 Universytetska St., 79000 Lviv, Ukraine.

${ }^{1}$ A humorous number-based error which could be translated as "I will do it without corpses", while the correct version should read "Zrobię to bez zwłoki" (I will do it without delay). 
the functional aspect of the meanings of collective, material, and abstract nouns which belong to the singularia tantum group, were studied in Polish by: Anna Andrzejczuk (2009), Andrzej Bogusławski (1973), Antonina Grybosiowa (1988), Andrzej Dyszak (1999, 2001), Kazimierz Feleszko (1980), Grażyna Habrajska (1995), Aleksandra Krupianka (1988), Piotr Krzyżanowski (1988, 2002), Ewa Rogowska (1992), and Olga Szapkina (2013, 2017); and in Ukrainian by: Lesia Altytseva (2003), Olena Bezpoiasko (1991), Vitalii Boretskyi (2008), Olha Eliashevska (2004), Andrii Kolesnykov (2000), Viacheslav Merinov (2012), Tetiana Moroz (2011, 2015, 2016), Inna Nazarenko (2008), Lubov Nedbailo (1968), and Ihor Pohribnyi (1999).

Despite the fact that so many researchers are interested in the category of number, there are few works related to the differences in the fulfilment of number forms in related Slavic languages. One attempt at comparing the applications of singular and plural forms of the names of fruit and vegetables in Polish and Russian was made by Olga Szapkina (1980). Jolanta Miturska-Bojanowska (2003) studied the use of singular and plural polysemic nouns in Polish and Russian. Some of the mistakes in the usage of nominal number forms in the Polish of Ukrainians was discussed by Ałła Krawczuk (2015, pp. 380-381). However, there are no detailed studies which would feature analyses of the areas in the usage of nominal number forms in Polish which cause problems to Ukrainians who learn the language. This article is intended to partly fill that gap.

Therefore, in this text I analyse Polish and Ukrainian nouns which differ in terms of how they fulfil the category of number. I analysed 80 Polish lexemes and their Ukrainian equivalents and the contexts of their usage in both languages. The study material was mainly collected from Polish language dictionaries (ISJP (2000); USJP (2003); WSPP (2004); WSJP (2007)) and Ukrainian language dictionaries (VTSSUM (2007); ILSSU (2007)), as well as corpora of the studied languages (in the case of Polish, I used the Polish National Corpus (hereinafter NKJP), and for Ukrainian: the Ukrainian Text Corpus (hereinafter KTUM)), and texts from the internet (using the Google search engine).

It would seem that the category of number, semantic for most nouns, should not cause any problems for Ukrainians learning Polish. And yet even at the basic levels of learning Polish, there appear lexemes which require additional grammatical clarification in terms of their number. Polish singularia tantum and pluralia tantum nouns may correspond to lexemes in Ukrainian of a different value of the number category (vide Table 1). 
Table 1. Polish singularia tantum and pluralia tantum nouns and corresponding lexemes in Ukrainian of a different value of the number category

\begin{tabular}{|c|c|}
\hline Polish & Ukrainian \\
\hline sentyment $[$ sentiment] & sentymenty (plural) \\
\hline zwłoka $[$ delay] & zvolikannia (singular) / zvolikannia (plural) \\
\hline skrzypce [violin] & skrypka/skrypky \\
\hline zajęcia [classes] & zaniattia (singular) / zaniattia (plural) \\
\hline binokle $[$ pince-nez] & realiia/realii \\
\hline realia [reality] & personaliia/personalii \\
\hline personalia [personal details] & kulinariia (singular) \\
\hline kulinaria [cuisine] & tekstyl (singular) \\
\hline tekstylia [textiles] & peryferiia (singular) \\
\hline peryferie $[$ outskirts] & \\
\hline
\end{tabular}

a The Polish word binokle and the Ukrainian binokl are so-called inter-linguistic homonyms. The Polish word denotes "glasses without the earpieces", while the Ukrainian denotes an "optical device used for dual-ocular observation of distant objects."

Source: own study

Unfamiliarity with the number differences of the quoted words often leads to using incorrect forms, which in turn disturbs communication or evokes a comical effect. For example, the Polish word zwloka denoting "delay in performance of something" (WSJP) is qualified in dictionaries as singulare tantum. Its Ukrainian equivalent of zvolikannia is a dual number word, e.g.: Ukrainian Ale sprava ne terpila zvolikannia [But the matter was urgent] (KTUM: Vynnychuk Yu. Khudozhnia proza, 2016), Ivetta vyrishyla bez zvolikan ziasuvaty stupin prychetnosti donchynoho kavalera do medytsyny [Ivetta decided to immediately find out about her daughter's companion's attitude to medicine](KTUM: Liuko Dashvar. Maty vse, 2010), Dopomoha ne terpyt zvolikan [Help hates delays] (https://ukurier.gov.ua, 2015). When using the word zwtoka, a Ukrainian person, under the influence of their mother tongue, may create structures with the plural form of the word (*bez zwtok, *nie ciepieć zwtok) which will lead to a misunderstanding as the word zwloki denotes "corpse; the body of a dead person or animal" (WSJP). Furthermore, learners may incorrectly understand the Polish contexts with plural 
forms, e.g. grać na skrzypcach (several?) [play the violin - in Polish "skrzypce" is a plurale tantum noun], spotkamy się na zajęciach (how many?) [we'll meet in class - the Polish word for "class" is "zajęcia", which, again, is a plurale tantum noun], or treat the plural form as singular, choose an incorrect declension pattern or distort the agreement with other elements in a sentence, e.g. Mieszkam na *peryferii [I live in the *periphery], Mocna strona imprezy *była kulinaria [The *cuisines were the strong point of the event]. ${ }^{2}$

The Ukrainian nouns included in the groups of singularia tantum and pluralia tantum may possess the complete number paradigm in Polish (Table 2).

Table 2. Ukrainian singularia tantum and pluralia tantum and corresponding Polish lexemes possessing the complete number paradigm

\begin{tabular}{|c|c|}
\hline Polish & Ukrainian \\
\hline makaron/makarony [pasta] & makarony (plural) \\
\hline rodzynek, rodzynka/rodzynki [rasin, rasins] & rodzynky (plural) \\
\hline debata/debaty [debate/debates] & debaty (plural) \\
\hline objęcie/objęcia [embrace/embraces] & obiimy (plural) \\
\hline kadra/kadry [staff] & kadry (plural) \\
\hline kpina/kpiny [mockery] & kpyny (plural) \\
\hline mebel/meble [piece/pieces of furniture] & mebli (plural) \\
\hline kurs/kursy [course/courses] & kursy (plural) \\
\hline zboże/zboża [cereal/cereals] & zbizhzhia (singular) \\
\hline kosmetyk/kosmetyki [cosmetic/cosmetics] & kosmetyka (singular) \\
\hline sport/sporty [sport/sports] & sport (singular) \\
\hline władza/władze [authorities] & vlada (singular) \\
\hline $\begin{array}{l}\text { informacja/informacje [piece/pieces } \\
\text { of information] }\end{array}$ & informatsiia (singular) \\
\hline
\end{tabular}

Source: own study

${ }^{2}$ For a more detailed analysis of Polish nouns used in the plural and their Ukrainian counterparts which are used in singular form (vide Bundza 2016). 
Some Ukrainian pluralia tantum denote phenomena which are both singular (e.g., the Ukrainian U Lvovi kandydatam u mery mozhut vlashtuvaty shche odni debaty [In Lviv, candidates running for mayor can get one more debates] (https://portal.lviv.ua, 2015), Tomu shvydko zapysalasia na movni kursy v odnu $z$ mistsevykh shkil [Therefore, she quickly signed up for language courses to one of the local schools] (https://www.dw.com, 2015)) and plural (e.g., the Ukrainian ... tobto po 18 rokakh riznykh debat Dekliaratsiia bula odnoholosno pryniata $i$ zatverdzhena Asambleieiu [so after 18 years of various debates the Declaration was uninamously passed and approved by the assembly] (www.unwla.org, 1979), Kolosalnyi rozvytok IT sfery u Lvovi ta v Ukraini zahalom porodzhuie takozh bezlich kursiv prohramuvannia [The huge boom in IT in Lviv and throughout Ukraine results also in the creation of many software development courses] (https://gs.lviv.ua, 2018)). Polish nouns used in plural form indicate plurality of designators (e.g., the Polish Kolejne dwie debaty z udziałem laureatów poświęcone byty literaturze [The following two debates with the prize-winners were devoted to literature] (NKJP: Polityka, 2003), Sa też prowadzone różne kursy językowe [There are also various language courses available] (NKJP: Wychowawca, 2009)), as singularity is conveyed by singular forms (e.g., ...każdy może przystuchiwać się, a nawet uczestniczyć w debacie [anyone can listen to, or even take part in the debate] (NKJP: Gazeta Wrocławska, 1999), ...jedna z nagród otrzymana w konkursie jest kurs języka włoskiego [one of the prizes in the competition is an Italian language course] (NKJP: Trybuna Śląska, 2001)). Therefore, one can assume that when using the plural forms of the words debata and kurs speakers of Ukrainian mean a singular referent: *Wziatem udziat $w$ debatach [I participated in debates], *Chce pójść na kursy językowe [I want to go on language courses], while plural forms in such contexts may be received by Poles as denoting plurality.

The words makaron [pasta] and kadra [staff] have a somewhat different nature, as their singular forms are collective (cf. respective definitions: makaron "non-sweet dough of flour, eggs and water, cut into various shapes, eaten as an addition to soups or main course" (WSJP); kadra "group of people specialising in a discipline, working in one company or in one institution" (WSJP), and the examples of their uses: zupa z makaronem [soup with pasta], makaron $w$ sosie [pasta in sauce]; kadra lekarzy [staff of doctors], zmienić kadre [change the staff]). However, the nature of the usage of the plural forms of those words is different: as indicated by the quoted examples and the NKJP data, it is often the case that the makaron lexeme is a singular form (in the WSJP there is only one example in plural: kolorowe makarony [coloured pasta]; in the normalised version of the corpus: 1,401 instances in singular and 182 in plural). Plural contexts denote, e.g., the many varieties, portions, packaging options, e.g.: the Polish Jezeli polskie makarony sq dziś mniej odległe jakościowo od włoskich czy hiszpańskich, 
jest to zastuga właśnie profesora Wolskiego [If Polish pastas are less distant in terms of quality from Italian or Spanish pasta, that is thanks to professor Wolski] (NKJP: Morawski Z. Gdzie ten dom, gdzie ten świat, 1994), Sa oczywiście wszelkie wyroby spożywcze, jak kasze, makki, makarony $i$ wiele innych artykutów potrzebnych $w$ każdym gospodarstwie domowym [Those are, of course, all food products, such as groats, flours, pastas, and many other products necessary in every household] (NKJP: EKO-U Nas, 2002), Najszybciej ida kurczaki, porcje rosolowe, makarony, cukier, kawa i wszelkie konserwy [The most sought-after are chickens, chicken stew meat portions, pastas, sugar, coffee, and all kinds of tinned goods] (NKJP: Polityka, 2009). In Ukrainian, in such contexts, the only possible form is the plural, i.e. makarony, e.g.: the Ukrainian Vrantsi znaishlasia voda, buly narubani drova, zvareni makarony [In the morning, there was water, wood was chopped, pastas were cooked] (KTUM: Ekspedytsiia, XXI, 2008), A-a, u vas zapasiv hrechky ta makaroniv na pivroku ye [Oh, you have stock piled buckwheat and pastas for 6 months] (KTUM: Dzerkalo tyzhnia, 2014), ... u komirkakh velykoi chastyny tamteshnikh pensioneriv uzhe stilky riznykh krupiv ta makaroniv (KTUM: Halychyna, 2015). Therefore, learners of Polish under the influence of Ukrainian may use plural forms where Poles would use singular forms: *zupa $z$ makaronami [soup with pastas], *makarony z sosem [pastas with sauce].

The number characteristics of the nouns wtadza [authorities], kosmetyk [cosmetic], and zboże [cereal] may cause problems to Ukrainians as their Ukrainian counterparts are not used in the plural. The word władza meaning "institutions, governing bodies managing something; also: people who govern and manage something" [USJP] is usually used in the plural form and classified in the pluralia tantum group, e.g., the Polish Polskie władze zbyt rzadko korzystaty z doświadczeń innych krajów przy restrukturyzacji czy wręcz likwidacji górnictwa [Polish authorities too rarely used the experiences of other countries in restructuring or ending mining] (NKJP: Szczepański J.J. Górnik polski, 2005). The corresponding Ukrainian word vlada with a similar meaning is a singulare tantum noun, e.g., the Ukrainian Yak rozporiadytsia ukrainska vlada piatma misiatsiamy, pokazhe chas [How Ukrainian authority will govern in five months, time will tell] (KTUM: Dzerkalo tyzhnia, 2009), which may result in Ukrainians not using the plural form of the word wtadza in Polish.

The Ukrainian noun kosmetyka denotes a group and a limitation of the number form, e.g., the Ukrainian ... pratsiuie armiia medykiv, farmatsevtiv, vyrobnykiv kosmetyky ta plastychnykh khirurhiv [There is working an army of physicians, pharmacists, manufacturers of cosmetic and plastic surgeons] (KTUM: Dzerkalo tyzhnia, 2012), ... odiahaietsia duzhe prostenko, zhodnoi kosmetyky [She dresses plainly, no cosmetic] (KTUM: unian.net, 2009). The Polish counterpart of the Ukrainian word which denotes a group is the plural form of the kosmetyk lexeme, e.g., the Polish Swoja fabryke producent kosmetyków zamierza wybudować do końca tego roku [The manufacturer of cosmetics intends to build its factory by 
the end of the year] (NKJP: Słowo Polskie, 2006), Kobiety podkreślaty urode wszelkimi sposobami, stosujac kosmetyki [Women emphasise their beauty with all available means, using cosmetics] (NKJP: Chwalba A. Obyczaje w Polsce..., 2004). To refer to a single product, it is possible in Ukrainian to use only the analytical structure (e.g. kosmetychnyj zasib), while in Polish for that meaning one uses the singular form of the word kosmetyk, e.g., in Polish ...jeśli masz jasna cerę, nie warto kusić się na kosmetyk przeznaczony do ciemnej skóry [if you have a light complexion, don't bother with a cosmetic intended for a dark complexion] (NKJP: Cosmopolitan, 2000). The situation with the use of the analysed words becomes further complicated due to the differences in terms of the category of gender: the Ukrainian lexeme kosmetyka is feminine. An incorrect use of singular form instead of plural denoting a group may be accompanied by an incorrect gender form, and, as a consequence, an incorrect selection of declension, e.g., promocja na *kosmetyke [special offer on cosmetics].

When discussing the category of number in Polish, one should also mention the fact that some dual-number nouns are used in one of the numbers in specific contexts, while in Ukrainian in the same contexts the other number is used, e.g.: the Polish bez problemu / nie ma problemu [no problem / there is no problem] with the singular form and the Ukrainian bez problem with the plural (e.g., the Polish ...w dodatku bez problemu znalazt miejsce na parkingu [additionally, he found a parking spot without a problem] (NKJP: Samson H. Pułapka na motyla, 2000), $Z$ tsym dokumentom vin bez problem zareiestruvavsia na reis [With this document, he checked in without any problems] (KTUM: UNIAN, 2017)). Another obstacle for the correct application of the Polish expression bez problemu is the gender difference of the words which results in the creation of a plural genitive of the word *problema according to an incorrect pattern: *bez problem. When teaching Ukrainians Polish, it is worth focussing on the noun informacja [information] which can take both the singular and the plural forms. A corpus analysis of the contexts with the uses of the words informacja [piece of information] and informacje [details] indicated a more common use of the plural form ${ }^{3}$, e.g. the Polish Wszelkie dodatkowe informacje, komunikaty będziemy podawać na bieżqco [We will communicate any additional details and announcements on a regular basis] (NKJP: Tygodnik Podhalański, 1997), Znajdziesz tu również szczegółowe informacje dotyczace konkursu [Here, you can also find the details regarding the competition] (NKJP: Cosmopolitan, 2000). The Ukrainian word informatsiia is a singulare tantum noun and it is not used in the plural form, e.g. the Ukrainian Takozh dodatkovu informatsiiu mozhna otrymaty $v$ odnoho z orhanizatoriv zakho$d u$ zakhodu [You can also receive an additional information from one of the proj-

${ }^{3}$ For example, a corpus analysis of the combination of the word informacja with adjectives dodatkowy [additional] and szczególowy [detailed] indicated a 70:1 ratio of contexts with the plural form to contexts with the singular form. 
ect organisers] (KTUM: Misto, 2013), Bilsh detalna informatsiia pro stvorennia i funktsionuvannia hromadivskykh rad $v$ Ukraini [A more detailed information on the establishing and functioning of territorial councils in Ukraine] (KTUM: Viche, 2014).

In Polish, the pluralia tantum group includes, apart from common nouns, proper nouns, including toponyms, the Ukrainian counterparts of which have the singular form (Table 3 ).

Table 3. Polish pluralia tantum toponyms, with the Ukrainian counterparts

\begin{tabular}{|c|c|}
\hline Polish & Ukrainian \\
\hline Czechy [Czechia] & Chekhiia (singular) \\
\hline Niemcy [Germany] & Nimechchyna (singular) \\
\hline Wegry [Hungary] & Uhorshchyna (singular) \\
\hline Włochy [Italy] & Italiia (singular) \\
\hline Chiny [China] & Kytai (singular) \\
\hline Indie [India] & Indiia (singular) \\
\hline Katowice & $\begin{array}{l}\text { Katovitse (singular, indeclinable) } \\
\text { (rarely Katovytsi (plural)) }\end{array}$ \\
\hline Kielce & $\begin{array}{l}\text { Keltse (singular, indeclinable) } \\
\quad(\text { rarely Keltsi (plural)) }\end{array}$ \\
\hline Gliwice & $\begin{array}{l}\text { Hlivitse (singular, indeclinable) } \\
\quad \text { (rarely Hlivytsi (plural)) }\end{array}$ \\
\hline
\end{tabular}

Source: own study

Therefore, when introducing the names of countries in class, it is worth emphasising those differences in order to help Ukrainian students avoid possible errors (*Bytem w Indii, *Jadę do Gliwice).

The analysed examples indicate several areas which are worth considering when teaching Polish to Ukrainian-speaking groups. Under the influence of Ukrainian, students may use incorrect forms of number (non-existent or which are not used in specific contexts), e.g. *bez zwłok, *na peryferii, *w Indii. The interferences from Ukrainian may induce them to use the plural form to denote singular referents instead of the proper singular forms (*uczestniczyć $w$ debatach ([participate in debates] instead of one debate), *zapisać na kursy ([sign up for courses] instead of one course), *zupa z makaronami [soup with pastas] instead of pasta). The fact that some Ukrainian nouns lack the plural form may cause abuses of the singula- 
ris counterparts in Polish instead of the correct plural form (informacja, wtadza). Speakers of Ukrainian may incorrectly understand Polish contexts with number forms, e.g., grać na skrzypcach ([play the violin] several?), rozmawiać o Czechach ([talk about the Czech Republic] talk about Czechs?). Therefore, when preparing Polish course material, one must remember about the differences in terms of the category of number to help students in Ukraine avoid possible errors.

\section{ABBREVIATIONS OF NAMES OF DICTIONARIES AND SOURCES}

ILSSU - Intehrovana leksykohrafichna systema ,, Slovnyky Ukrainy”, 2007, [CD-ROM 3.1]. ISJP - Inny stownik języka polskiego, 2000, M. Bańko (ed.), vol. I-II, Warsaw.

KTUM - Korpus tekstiv ukrainskoi movy, [online] http://www.mova.info [26.05.2019].

NKJP - Narodowy Korpus Języka Polskiego (Polish National Corpus), [online] http://www.nkjp.pl [26.05.2019].

USJP - Uniwersalny stownik języka polskiego, 2003, S. Dubisz (ed.), vol. I-IV, Warsaw.

VTSSUM - Velykyi tlumachnyi slovnyk suchasnoi ukrainskoi movy, 2007, V.T. Busla, Kyiv, Irpin.

WSJP - Wielki słownik języka polskiego, 2007, P. Żmigrodzki (ed.), [online] http://www.wsjp.pl [26.05.2019].

WSPP - Wielki słownik poprawnej polszczyzny PWN, 2004, A. Markowski (ed.), Warsaw.

\section{REFERENCES}

Altytseva L. Yu., 2003, Funktsionalno-semantychni parametry imennykiv z nepovnoiu chyslovoiu paradyhmoiu: avtoref. dys. na zdobuttia nauk. stupenia kand. filol. nauk, Kiev.

Andrzejczuk A., 2007, (Nie) tylko w liczbie mnogiej. Rozważania o szeroko rozumianych plurale tantum, „LingVaria”, vol. II, pp. 177-188.

Andrzejczuk A., 2009, Co jest, a czego nie ma? Oto jest pytanie! Potencjalizmy i defektywizmy w języku polskim, „Biblioteka LingVariów”, vol. 3, M. Skarżyński, A. Czelakowska (eds.), pp. 9-17.

Bezpoiasko O. K., 1991, Imenni hramatychni katehorii (funktsionalnyi analiz), Kiev.

Bogusławski A., 1973, Nazwy pospolite przedmiotów konkretnych i niektóre właściwości ich form liczbowych i połaczeń z liczebnikami w języku polskim, in: Z. Topolińska, M. Grochowski (eds.), Liczba, ilość, miara. Materiały Konferencji Naukowej w Jadwisinie, 11-13 maja 1972 r., Wrocław, Warsaw, Krakow, Gdańsk, pp. 7-36.

Boretskyi V. V., 2008, Vzaiemoperekhody v semantyko-hramatychnii katehorii ,konkretni - abstraktni imennyky”, „Linhvistychni studii”, vyp. 16, pp. 46-51.

Cieślikowa A., 1992, Liczba mnoga czy plurale tantum?, „Język Polski”, vol. LXXII, col. 4-5, pp. 362-364.

Degtyarev V. I., 1987, Plyuralizatsiya imen sobiratelnyh v istorii slavyanskih yazykov, „Voprosy yazyikoznaniya", no. 5, pp. 59-73.

Degtyarev V. I., 1989, Baltiyskie dannye v sravnitelno-istoricheskom izuchenii kategorii chisla slavyanskih yazykov, „Baltistica”, wyp. III, pp. 40-49.

Dyszak A., 1999, Rzeczowniki defektywne, „Język Polski”, vol. LXXIX, col. 1-2, pp. 79-92.

Dyszak A., 2001, Rzeczowniki i czasowniki defektywne w systemie fleksyjnym wspótczesnej polszczyzny, „Bulletin de la Société Polonaise de Linguistique”, vol. LVII, pp. 141-154. 
Eliashevska O. V., 2004, Do pytannia pro katehoriiu chysla imennykiv u suchasnomu ukrainskomu movoznavstvi, „Visnyk Lvivskoho un-tu. Seriia filolohichna”, vyp. 34, ch. I, pp. 134-139.

Feleszko K., 1980, Funkcje form kategorii liczby w polskiej grupie imiennej, Warsaw.

Friedelówna T., 1968, Kategoria plurale tantum w języku polskim, Toruń-Poznań.

Gradkowska J., 1989, Charakterystyka fleksyjna rzeczowników plurale tantum (na materiale Stownika języka polskiego PAN pod red. W. Doroszewskiego), „Studia z polskiej leksykografii współczesnej”, vol. III, Z. Saloni (ed.), pp. 145-162.

Grybosiowa A., 1988, Funkcje leksemów liczby mnogiej rzeczownika w języku prasy, radia i telewizji, in: W. Gruszczyński, G. Majkowska, H. Satkiewicz (eds.), Wybór tekstów do nauki o języku polskim dla studentów dziennikarstwa, Warsaw, pp. 247-254.

Habrajska G., 1995, Collectiva w języku polskim, Łódź.

Kolesnykov A. O., 2000, Syntahmatychna paradyhmatyka katehorii chysla morfolohichno nedostatnikh imennykiv: avtoref. dys. na zdobuttia nauk. stupenia kand. filol. nauk, Odessa.

Korin O., 2010, Semantychna struktura imennykiv pluralia tantum u "Slovari ukrainskoi movy" B. Hrinchenka ta v "Slovnyku ukrainskoi movy”, „Visnyk Lvivskoho universytetu. Seriia filolohichna", vyp. 34, ch. 1, pp. 140-147.

Krawczuk A., 2015, Wspólne interferencje gramatyczne z języków wschodniosłowiańskich w polszczyźnie mieszkańców Ukrainy, Białorusi, Rosji, in: I. Bundza, J. Kowalewski, A. Krawczuk, O. Sływyński (eds.), Język polski i polonistyka w Europie Wschodniej: przeszłość i współczesność, pp. 374-391.

Krupianka A., 1988, Wahania i zmiany w kategorii liczby rzeczowników w języku Mickiewicza, in: T. Skubalanka (ed.), Stylistyczna akomodacja systemu gramatycznego, Wrocław, pp. 81-90.

Krzyżanowski P., 1988, Kategoria liczby jako wykładnik odrębności leksykalnej, „Z polskich studiów slawistycznych" series 7, J. Basara (ed.), pp. 231-236.

Krzyżanowski P., 2002, Funkcjonowanie rzeczowników defektywnych w wypowiedzeniu, „Bulletin de la Société Polonaise de Linguistique", col. 58, pp. 149-156.

Merinov V. V., 2012, Vzaiemodiia hramatychnykh form chysla imennyka iz semantychnoiu katehoriieiu „rakhovanist - nerakhovanist”, „Naukovi zapysky. Seriia: Filolohichni nauky (movoznavstvo)", vyp. 105(1), pp. 8-12.

Miturska-Bojanowska J., 2003, Rosyjskie i polskie rzeczowniki polisemiczne $w$ aspekcie kategorii liczby, Szczecin.

Moroz T. Yu., 2011, Rozriad zbirnykh imennykiv u konteksti katehorii chysla yak vyiav semantyko-hramatychnoi asymetrii, „Linhvistychni doslidzhennia”, vyp. 32, pp. 191-194.

Moroz T. Yu., 2015, Semantyko-hramatychna asymetriia $v$ systemi morfolohichnoi katehorii chysla abstraktnykh imennykiv, „Odeskyi linhvistychnyi visnyk”, no. 15, pp. 99-102.

Moroz T. Yu., 2016, Morfolohichna katehoriia chysla imennykiv: pohliady doslidnykiv, „Linhvistychni doslidzhennia", vyp. 42, pp. 52-57.

Nazarenko I. O., 2007, Hramatychna transpozytsiia katehorii chysla imennykiv singularia tantum i movna norma, ,Linhvistychni studii”, vyp. 15, pp. 164-169.

Nazarenko I. O., 2008, Funktsionalno-stylistychni osoblyvosti imennykh chastyn movy, vzhyvanykh u znachenni hiperbolichnoi mnozhyny, „Visnyk Zaporizkoho natsionalnoho universytetu. Filolohichni nauky", no. 1, pp. 124-129.

Nedbailo L. I., 1968, Mnozhyna vid imennykiv rechovynnoho znachennia, „Pytannia movnoi kultury", vyp. 2, pp. 61-68.

Pohribnyi I. I., 1999, Materialno-rechovynni imennyky (leksychna semantyka i slovozmina): avtoref. dys. na zdobuttia nauk. stupenia kand. filol. nauk, Kiev.

Rogowska E., 1991, Kategoria plurale tantum w funkcji formantu słowotwórczego, „Język Polski”, vol. LXXI, col. 3-5, pp. 213-220.

Rogowska E., 1992, O formach liczbowych nazw owoców we wspótczesnej polszczyźnie, „Język Polski", vol. LXXII, col. 4-5, pp. 265-271.

Szapkina O., 1980, O osobliwościach użycia form liczby pojedynczej i mnogiej rosyjskich i polskich nazw owoców i jarzyn, „Poradnik Językowy”, col. 5, pp. 228-239. 
Szapkina O., 2013, Do trzech razy sztuka. O kwantytatywności w polskim językowym obrazie świata, „Kwartalnik Polonicum”, issue 13, pp. 8-16.

Szapkina O. N., 2017, Osobennosti chislovogo povedeniya predikatnyh imen suschestvitelnyh $v$ polskom yazyke, „Yazyk, soznanie, kommunikatsiya”, vol. 55, V. V. Krasnych (ed.), pp. 314-323.

Tambor J., 2017, Niektóre ,akademickie” pluralia tantum - semantyka, pragmatyka, struktura, „Postscriptum Polonisyczne”, issue 1(19), pp. 53-69.

Ternova A. I., 2004, Dynamika nulsufiksalnoho tvorennia imennykiv pluralia tantum v novii ukrainskii movi, „Visnyk Zhytomyrskoho derzhavnoho universytetu imeni Ivana Franka”, vyp. 14, pp. 188-193.

Żurowski S., 2014, Bez focha o fochach - foch i fochy jako nazwy werbalnych i niewerbalnych zachowań komunikacyjnych. Szkic leksykologiczny, https://repozytorium.umk.pl/bitstream/ handle/item/2377/s_zurowski_036.pdf?sequence=1 [26.05.2019].

Iryna Bundza

\section{ZROBIĘ TO BEZ ZWLOK... KATEGORIA LICZBY W NAUCZANIU JĘZYKA POLSKIEGO JAKO OBCEGO OSÓB UKRAIŃSKOJĘZYCZNYCH}

Słowa kluczowe: kategoria liczby, rzeczowniki singularia tantum, rzeczowniki pluralia tantum, nauczanie języka polskiego jako obcego, język polski, język ukraiński

Streszczenie. Artykuł przedstawia osobliwości kategorii liczby polskich i ukraińskich rzeczowników. W celu wskazania trudnych miejsc związanych z nauczaniem kategorii liczby osób ukraińskojęzycznych przeanalizowano polskie i ukraińskie leksemy pod względem realizacji wartości gramatycznej kategorii liczby. Przedstawiono konteksty, w których możliwe jest popełnianie błędów, co może wywołać efekt komiczny lub zakłócić komunikację. Źródłem informacji są słowniki języka polskiego i ukraińskiego, a także zasoby Narodowego Korpusu Języka Polskiego oraz Korpusu Tekstów Języka Ukraińskiego. 